\title{
Structurally Diverse Metabolites from the rare Actinobacterium Saccharothrix xinjiangensis
}

Zahra Khosravi Babadi ${ }^{1,2, \uparrow}$, Enge Sudarman ${ }^{3,4, \uparrow}$, Gholam Hossein Ebrahimipour ${ }^{1}$, Gian Primahana $^{3,4}$, Marc Stadler ${ }^{3,4}$ and Joachim Wink ${ }^{2,4, *}$

${ }^{1}$ Department of Microbiology \& Microbial Biotechnology, Faculty of Life Sciences and Biotechnology, Shahid Beheshti University GC, Tehran, Iran.

${ }^{2}$ Microbial Strain Collection, Helmholtz Centre for Infection Research GmbH (HZI), Inhoffenstrasse 7, 38124 Braunschweig, Germany.

${ }^{3}$ Department Microbial Drugs, Helmholtz Centre for Infection Research GmbH (HZI), Inhoffenstrasse 7, 38124 Braunschweig, Germany.

${ }^{4}$ German Centre for Infection Research Association (DZIF), Partner site Hannover-Braunschweig, Inhoffenstrasse 7, 38124 Braunschweig, Germany.

Correspondence: Dr. Joachim Wink, Helmholtz Centre for Infection Research GmbH, Working Group Microbial Strain Collection, Inhoffenstraße 7, 38124 Braunschweig, Germany.

Email: Joachim.wink@helmholtz-hzi.de

\begin{abstract}
The bioassay-guided fractionation from cultures of the actinobacterium Saccharothrix xinjiangensis Act24Zk, collected from the Caspian Sea beach in Iran led to the isolation of three new compounds, caerulomycin M (1), saccharopyrone (2) and saccharonoic acid (3), together with the known compound, caerulomycin A (4). Their structures were elucidated from HRESIMS and 1D and 2D NMR data. Compound 2 displayed moderate cytotoxic activity against the human cervix carcinoma HeLa cells $\mathrm{KB} 3.1$ with an $\mathrm{IC}_{50}$ value of $5.4 \mu \mathrm{M}$.
\end{abstract}

Keywords: acid hydrolysis/ cyctotoxic activity/ NOE/ rhamnose/ Saccharothrix xinjiangensis

\section{INTRODUCTION}

$\triangle \bowtie \dagger$ These authors contributed equally to this work. 
It is estimated that by 2050 about 10 million people per year would be dying from antibiotic-resistant infections, which has led to an increasing demand of new active drugs. ${ }^{1,2}$ Out of the 23,000 known microbial bioactive secondary metabolites ${ }^{3}$ more than $75 \%$ are derived from actinobacteria, in particular from the genus Streptomyces. Many of these compounds are selective antibiotics, or anticancer, antifungal and immunosuppressive agents. ${ }^{4,5}$ In recent years other genera of the so-called rare actinobacteria have increasingly become attractive resources of novel biological active secondary metabolites..$^{6,7,8,9,10}$ Of these, the genus Saccharothrix has been reported to produce a range of bioactive compounds such as the antibacterial agents tianchimycins A-B from Saccharothrix xinjiangensis, ${ }^{11}$ the antitumor agent saccharothriolide B from Saccharothrix sp. ${ }^{1212}$ and the antifungal antibiotic formamicin from Saccharothrix tangerines sp. nov. ${ }^{13}$ As part of our ongoing research to discover new bioactive compounds from our collected actinomycetes, which had been isolated from soil samples from different areas of Iran, the strain Act24Zk was selected for further study due to the strong antibacterial and antifungal activities during bioassay screening. Herein we report the isolation, spectroscopic structural elucidation and biological activities of three unprecedented metabolites, caerulomycin M (1), saccharopyrone (2), saccharonoic acid (3) and the known caerulomycin A (4) from the culture of Act24Zk (Figure 1).

\section{RESULTS AND DISCUSSION}

Phylogenetic analysis showed that strain Act24Zk, isolated from a beach on the Caspian Sea of Iran, has a high 16S rRNA nucleotide sequence similarity to S. xinjiangensis $(99.5 \%)$, a species that was first isolated from Tianchi Lake, Xinjiang Uygur Autonomous Region, China. ${ }^{14}$ Strong activities against Staphylococcus aureus and Mucor hiemalis were found in the ethyl acetate extract of the cell mass of Act24Zk. After removing the lipophilic by-product by a partition between methanol and heptane, the residue of the extract was separated by Sephadex LH-20 in methanol, followed by preparative RP-18 of the LH-20 fractions to give caerulomycin M (1), saccharopyrone (2) and saccharonoic acid (3), along with caerulomycin A (4). Their structures were elucidated by HR-ESIMS and 2D NMR spectroscopy.

The molecular formula of $\mathrm{C}_{18} \mathrm{H}_{21} \mathrm{~N}_{3} \mathrm{O}_{6}$ was identified as caerulomycin $\mathrm{M}$ (1) from the HRESIMS spectrum of the molecular ion cluster $[\mathrm{M}+\mathrm{H}]^{+}$at $m / z 376.1509$ (calcd for $\mathrm{C}_{18} \mathrm{H}_{22} \mathrm{~N}_{3} \mathrm{O}_{6}$ 376.1503 ) and $[2 \mathrm{M}+\mathrm{Na}]^{+}$at $m / z 773.2738$ (calcd for $\mathrm{C}_{36} \mathrm{H}_{42} \mathrm{~N}_{6} \mathrm{NaO}_{12}$ 773.2753), implying the presence of ten degrees of unsaturation. Its complete structure was determined by $1 \mathrm{D}$ and $2 \mathrm{D}$ NMR spectroscopy. The ${ }^{13} \mathrm{C}$ NMR and ${ }^{1} \mathrm{H},{ }^{13} \mathrm{C}$ HSQC NMR spectral data confirmed the presence of 18 carbons, including seven olefinic methines $\left(\delta_{\mathrm{H}} 7.37-8.70, \delta_{\mathrm{C}} 151.3-106.9\right)$, four quaternary olefinic carbons $\left(\delta_{\mathrm{C}} 166.8-151.9\right)$, five oxymethines $\left(\delta_{\mathrm{H}} 3.29-5.35, \delta_{\mathrm{C}} 103.0\right.$ $69.1)$, one methoxy carbon $\left(\delta_{\mathrm{H} / \mathrm{C}} 3.97 / 55.8\right)$ and one methyl group $\left(\delta_{\mathrm{H} / \mathrm{C}} 1.15 / 18.0\right)$. The ${ }^{1} \mathrm{H}$ NMR spectrum provided further three hydroxyl groups $\left(\delta_{\mathrm{H}} .5 .08,4.90,4.78\right)$. Analysis of the ${ }^{1} \mathrm{H},{ }^{1} \mathrm{H}$ COSY and ${ }^{1} \mathrm{H},{ }^{13} \mathrm{C}$ HMBC correlations revealed the presence of the 2,2'-bipyridine 
moiety (Figure 2). The NMR spectra of bipyridine moiety were very similar to those of caerulomycin $\mathrm{A},{ }^{15}$ indicating the existence of a caerulomycin A analogue. COSY correlations from H-2" to H-6", in conjunction with the HMBC correlation of H-5" to C-1" suggested the presence 6-deoxyhexose sugar moiety. This was identified to be $\alpha$-rhamnopyranose by comparison of the ${ }^{1} \mathrm{H}$ and ${ }^{13} \mathrm{C}$ spectroscopic data with those reported in the literature, ${ }^{16}$ which was confirmed by ROESY data and coupling constant analysis. Furthermore, the characteristic small coupling constant of the anomeric proton at $\mathrm{C}-1$ " $(<2 \mathrm{~Hz})$ supported the $\alpha$-configuration and an NOE correlation between H-6 and H-1" indicated the $E$-configuration of the oxime moiety. The absolute configuration of rhamnose was determined to be $\mathrm{L}$ after acid hydrolysis by comparison of the specific rotation of the pure sugar moiety $\left(\mathbf{1 a}[\alpha]^{20} \mathrm{D}\right.$ $\left.+16.0, \mathrm{H}_{2} \mathrm{O}\right)$ with that of standard $\mathrm{L}(+)$-rhamnose $\left([\alpha]^{20}{ }_{\mathrm{D}}+18.8, \mathrm{H}_{2} \mathrm{O}\right)$. Thus, the structure of 1 was determined to be (4-methoxy[2,2'-bipyridin]-6-methylidene]amino)oxy-6- $\alpha$ - Lrhamnopyranoside.

Lahoum et al. ${ }^{17}$ have recently published two bipyridine glycosides isolated from another Saccharothrix strain. One of the glycosides, cyanogriside $\mathrm{J}$, has a similar structure to $\mathbf{1}$. The authors stated that the sugar moiety of cyanogriside $J$ should be 2,4-dimethyl- $\alpha$ - L-mannose, but did not provide any detailed data concerning the relative and absolute configurations of the molecule. We here report, based on the NMR data and sugar analysis by specific rotation determination that $\mathbf{1}$ has different sugar moiety than cynogriside $\mathrm{J}$.

Saccharopyrone (2) exhibited in the HR-ESIMS spectrum a molecular ion peak cluster $[\mathrm{M}+\mathrm{Na}]^{+}$at $m / z 451.1937$ (calcd for $\mathrm{C}_{21} \mathrm{H}_{32} \mathrm{NaO}_{9} 451.1939$ ) and $[2 \mathrm{M}+\mathrm{Na}]^{+}$at $\mathrm{m} / z 879.3980$ (calcd for $\mathrm{C}_{42} \mathrm{H}_{64} \mathrm{NaO}_{18} 879.3985$ ) which provided the elemental formula $\mathrm{C}_{21} \mathrm{H}_{32} \mathrm{O}_{9}$ (6 DBE). The ${ }^{13} \mathrm{C}$ NMR and ${ }^{1} \mathrm{H},{ }^{13} \mathrm{C}$ HSQC NMR data of 2 implied the presence of five quaternary olefinic carbons $\left(\delta_{\mathrm{C}} 171-101\right)$ including two carbonyl carbons $\left(\delta_{\mathrm{C}} 170.4\right.$ and 164.5), one olefinic methine $\left(\delta_{\mathrm{H} / \mathrm{C}} 6.46 / 96.4\right)$, five oxymethines $\left(\delta_{\mathrm{H}} 3.28-5.59, \delta_{\mathrm{C}} 97.9-69.7\right)$, four methylenes $\left(\delta_{\mathrm{H}} 1.13-2.48, \delta_{\mathrm{C}} 25.3-32.8\right)$, one methine $\left(\delta_{\mathrm{H} / \mathrm{C}} 1.71 / 31.9\right)$ and three methyl groups $\left(\delta_{\mathrm{H} / \mathrm{C}} 2.01 / 20.7,1.79 / 8.5,0.86 / 16.6\right)$. In addition, the downfield shift of proton signals at 3.79 and 3.87 with the corresponding carbon at 68.4 suggested the fifth methylene group positioned to oxygen. The ${ }^{1} \mathrm{H},{ }^{1} \mathrm{H}$ COSY spectrum showed a contiguous aliphatic chain from $\mathrm{H}-1^{\prime}$ to $\mathrm{H}-6$ ' which was connected to the methyl acetate from ${ }^{1} \mathrm{H},{ }^{13} \mathrm{C}$ HMBC correlations of $\mathrm{H}_{2}-6$ ' to $\mathrm{C}-\mathrm{7}^{\prime}$, and of methyl $\mathrm{H}_{3}-8$ to $\mathrm{C}-7$ ', respectively (Figure 3). An aromatic unit was identified as 3-methyl-2-oxo-2 $\mathrm{H}$-pyran by detailed analysis of further correlations. The ${ }^{1} \mathrm{H}$ and ${ }^{13} \mathrm{C}$ NMR data of the sugar moiety were very similar to those of compound $\mathbf{1}$ and of the reported literature precedent for the L-rhamnose. Detailed analysis of 2D NMR data confirmed the presence of $\alpha$ - L-rhamnopyranoside with the small coupling constant $(1.9 \mathrm{~Hz})$ of the anomeric proton (H-1"). Finally, HMBC correlations from $\mathrm{H}-1$ " to C-4 and from $\mathrm{H}-1$ ' to C-6 and C-5 linked the $\alpha$-pyrone unit to the sugar moiety and the side chain, completing the 
structure of $2^{1}$. Therefore, 2 was identified to be 2-methyl-6-(3-methyl-2-oxo-2H-pyran-6-yl) hexylacetate- 6- $\alpha$ - L-rhamnopyranoside.

$\alpha$-pyrones are known to be derived from the polyketide synthase (PKS) pathway. ${ }^{18}$ Compound 2 is probably assembled by the condensation of two polyketide chains by the catalytic activity of a free standing KS and subsequently the O-linked glycosylation forms the final structure. Examples for such a mechanism are corallopyronins and myxopyronins, which are biosynthesized via interconnection of two linear polyketide chains by the stand-alone ketosynthese enzyme CorB and MxnB, respectively. ${ }^{19,20}$ However, feeding studies and analysis of biosynthetic gene cluster of $\mathbf{2}$ remain necessary to prove this biosynthetic hypothesis.

The elemental formula $\mathrm{C}_{22} \mathrm{H}_{37} \mathrm{NO}_{3}(5 \mathrm{DBE})$ of saccharonoic acid (3) was determined by HR-ESIMS of the molecular ion cluster $[\mathrm{M}+\mathrm{H}]^{+}$at $\mathrm{m} / z 364.2842$ (calcd for $\mathrm{C}_{22} \mathrm{H}_{38} \mathrm{NO}_{3}$ 364.2846) and $[2 \mathrm{M}+\mathrm{H}]]^{+}$at $m / z 727.5601$ (calcd for $\mathrm{C}_{44} \mathrm{H}_{75} \mathrm{~N}_{2} \mathrm{O}_{6} 727.5620$ ). The ${ }^{13} \mathrm{C}$ and ${ }^{1} \mathrm{H},{ }^{13} \mathrm{C}$ HSQC NMR data confirmed the carbon number and showed the presence of two carbonyl carbons $\left(\delta_{\mathrm{C}} 171.2\right.$ and 165.5), two quaternary olefinic carbons $\left(\delta_{\mathrm{C}} 133.1\right.$ and 130.5), three olefinic methines $\left(\delta_{\mathrm{H}} 7.01-5.04, \delta_{\mathrm{C}} 145.7-126.0\right)$, three methines $\left(\delta_{\mathrm{H}} 2.63,1.53,1.51 \delta_{\mathrm{C}} 30.6\right.$, $28.1,26.9)$, five methylenes $\left(\delta_{\mathrm{H}} 1.97-1.09, \delta_{\mathrm{C}} 47.0-25.2\right)$ and six methyl groups $\left(\delta_{\mathrm{H}}\right.$ $\left.1.75-0.76, \delta_{\mathrm{C}} 22.4-15.5\right)$. The ${ }^{1} \mathrm{H}$ NMR spectrum in DMSO showed further an NH signal at 8.05. The planar structure of 3 was elucidated from the ${ }^{1} \mathrm{H},{ }^{1} \mathrm{H}$ COSY and ${ }^{1} \mathrm{H},{ }^{13} \mathrm{C}$ HMBC correlations which provided the connection through secondary amide bond and the attachment of carboxyl residue (Figure 4). The $E$ configuration of the $\Delta^{5,6}$ double bond was assigned from the coupling constant of $15.5 \mathrm{~Hz}$. The methyl substituted $\Delta^{7,8}, \Delta^{13,14}$ double bonds were established as trans from the ${ }^{1} \mathrm{H},{ }_{1}^{1} \mathrm{H}$ ROESY correlations of methyl-19 and $\mathrm{H}-5$ and between H-6 and H-8, as well as of methyl-22 and $\mathrm{H}_{2}-15$ and between $\mathrm{H}_{2}-12$ and $\mathrm{H}-14$.

Further, an energy minimized conformation of $\mathbf{3}$, which was calculated by MM2 with ChemBio3D 17.1., in combination with the observed NOEs allows to propose a relative configuration of dimethylated stereo centers at C-9 and C-11 as shown in Figure 5. This presents the preferential conformation of the carbon chain by avoidance of the high-energy syn-pentane interactions. ${ }^{21}$ As expected from the model, significant $\mathrm{NOEs}$ from $\mathrm{CH}_{3}-19$ to $\mathrm{H}$ 5 and $\mathrm{H}-9$ positioned $\mathrm{H}-9$ syn to $\mathrm{H}-5$. On the other side, NOE correlations from $\mathrm{H}-11$ to $\mathrm{CH}_{3}-$ 20 and $\mathrm{CH}_{3}-22$ and from $\mathrm{CH}_{3}-20$ to $\mathrm{H}-8$ placed $\mathrm{H}-11$ on the same face as $\mathrm{H}-8$. Thus, both C-9 and C-11 stereo centers occupy the relative syn configuration. All further NOEs are in good agreement with the conformation of compound 3. On this basis, $\mathbf{3}$ was proposed as $\{[(2 E, 4 E, 6 S, 8 R, 10 E)-4,6,8,10,14$-pentamethyl-pentadeca-2,4,10-trienoyl $]$ amino $\}$ acetic acid.

1 The complete absolute configuration of compound 2 resulted in hydrolysis of acetate and subsequently derivatization of the consequence alcohol according to modified Mosher's method couldn't be determined due to the low amount of compound 2. 
The structure of $\mathbf{3}$ bearing 1,3-dimethylated hydrocarbon segment appears frequently as structural elements in polyketide natural products. ${ }^{22}$ Some macrocyclic polyketides such as narbonolide and methymycin isolated from Streptomyces species have been previously reported to occupy syn conformation of their 1,3- dimethyl substituted chain segment. ${ }^{23,24,25}$

Compounds 1-4 were evaluated for their antimicrobial and cytotoxic activities. Compound $\mathbf{1}$ showed moderate activity against $M$. hiemalis, whereas $\mathbf{3}$ exhibited weak activity against $M$. hiemalis and Candida albicans. Compound $\mathbf{2}$ did not show any antimicrobial activities at concentrations $\leq 66.7 \mu \mathrm{g} \mathrm{ml}^{-1}$. Compound 4 is known to exhibit antibacterial and antifungal activity, ${ }^{26}$ which is also confirmed against our test microorganisms except $C$. albicans. In the cytotoxicity assay compound $\mathbf{1}$ exhibited weak cytotoxicity against KB3.1 and L929 cell lines, whereas compound $\mathbf{2}$ showed significant inhibition against KB3.1 cell line. Compound $\mathbf{3}$ had no activity against our test cell lines. Compound $\mathbf{4}$ was most potent, showing inhibition against KB3.1 and $\mathrm{L} 929$ cell lines in the $\mathrm{IC}_{50}$ range of $0.1-0.2 \mu \mathrm{M}$. The presence of the sugar moiety of compound $\mathbf{1}$ in the corresponding aglycone $\mathbf{4}$ weakened the antimicrobial effects and also led to a significant decrease in cytotoxicity.

\section{CONCLUSION}

Our work on the culture broth of Saccharotrix strain Act24Zk resulted in the isolation and characterization of a new bipyridine glycoside, caerulomycin $M$ (1), a new $\alpha$-pyrone glycoside, saccharopyrone (2) and a new polyketide, saccharonoic acid (3), together with one known caerulomycin A (4). The evaluation of antimicrobial and cytotoxic activities of compounds 1-3 revealed that $\mathbf{1}$ and $\mathbf{3}$ exhibited moderate to weak activities against $M$. hiemalis, whereas compound $\mathbf{2}$ displayed significant activity against KB3.1 cells.

\section{EXPERIMENTAL SECTION}

\section{General Experimental Procedures}

Fractionation and analytical RP HPLC were carried out with an Agilent 1100 HPLC system equipped with a diode-array UV detector, a fraction collector and a Corona Ultra detector (Dionex). HPLC conditions: XBridge C18 column $100 \times 2.1 \mathrm{~mm}$ (Waters), $3.5 \mu \mathrm{m}$, solvent A $\left[\mathrm{H}_{2} \mathrm{O}\right.$-acetonitrile $\left.(95: 5, \mathrm{v} / \mathrm{v}), \quad 5 \mathrm{mmol} \mathrm{NH}_{4} \mathrm{Ac}, \quad 0.04 \mathrm{ml} \mathrm{l}^{-1} \mathrm{CH}_{3} \mathrm{COOH}\right]$; solvent B $\left[\mathrm{H}_{2} \mathrm{O}\right.$-acetonitrile $\left.(5: 95, \mathrm{v} / \mathrm{v}), 5 \mathrm{mmol} \mathrm{NH} \mathrm{NH}_{4} \mathrm{Ac}, 0.04 \mathrm{ml} \mathrm{l}^{-1} \mathrm{CH}_{3} \mathrm{COOH}\right]$; gradient system, from $10 \% \mathrm{~B}$ to $100 \% \mathrm{~B}$ in $30 \mathrm{~min}$ and maintaining $100 \%$ for $10 \mathrm{~min}$; flow rate $0.3 \mathrm{ml} \mathrm{min}{ }^{-1} ; 40{ }^{\circ} \mathrm{C}$. Preparative HPLC purification was performed on an Agilent 1100 series preparative HPLC system [ChemStation software (Rev. B.04.03 SP1); binary pump system; diode-array UV detector; 180-fraction collector]. HRESIMS (High resolution electronspray ionization mass spectrometry) data were recorded on a MaXis ESI TOF mass spectrometer (Bruker Daltonics) 
[scan range $\mathrm{m} / \mathrm{z} 100-2500$, rate $2 \mathrm{~Hz}$, capillary voltage $4500 \mathrm{~V}$, dry temperature $200{ }^{\circ} \mathrm{C}$ ] equipp with an Agilent 1260 series HPLC-UV system (Agilent Technologies) (Santa Clara, CA, USA) [column $2.1 \times 50 \mathrm{~mm}, 1.7 \mu \mathrm{m}, \mathrm{C} 18$ Acquity UPLC BEH (Waters), solvent $\mathrm{A}: \mathrm{H}_{2} \mathrm{O}$ $+0.1 \%$ formic acid; solvent $\mathrm{B}$ : acetonitrile $(\mathrm{ACN})+0.1 \%$ formic acid, gradient: $5 \% \mathrm{~B}$ for 0.5 min, increasing $19.5 \mathrm{~min}$ to $100 \% \mathrm{~B}$, holding $5 \mathrm{~min}$ at $100 \% \mathrm{~B}$; flow $=0.6 \mathrm{ml} \mathrm{min}{ }^{-1}, 40^{\circ} \mathrm{C}$; DAD-UV detection at 200-600 nm]. Molecular formulas were calculated including the isotopic pattern (Smart Formula algorithm). HPLC DAD MS analysis was performed using an amaZon speed ETD ion trap mass spectrometer (Bruker Daltonics) in positive and negative ionization modes. The mass spectrometer was coupled to a Dionex UltiMate 3000 HPLC system [column $2.1 \times 50 \mathrm{~mm}, 1.7 \mu \mathrm{m}, \mathrm{C} 18$ Acquity UPLC BEH (Waters), solvent $\mathrm{A}: \mathrm{H}_{2} \mathrm{O}+$ $0.1 \%$ formic acid; solvent $\mathrm{B}$ : acetonitrile $(\mathrm{ACN})+0.1 \%$ formic acid, gradient: $5 \% \mathrm{~B}$ for 0.5 min, increasing to $100 \% \mathrm{~B}$ in $20 \mathrm{~min}$, maintaining isocratic conditions at $100 \% \mathrm{~B}$ for $10 \mathrm{~min}$, flow $=0.6 \mathrm{ml} \mathrm{min}^{-1}, \mathrm{UV}-$ vis detection 200-600 nm]. NMR spectra were recorded on a Bruker $700 \mathrm{MHz}$ Avance III spectrometer with a $5 \mathrm{~mm}$ TCI cryoprobe $\left({ }^{1} \mathrm{H}: 700 \mathrm{MHz},{ }^{13} \mathrm{C}: 175\right.$ $\mathrm{MHz}$ ), locked to the deuterium signal of the solvent. Chemical shifts are given in parts per million (ppm), and coupling constants in hertz (Hz). UV/vis spectra were measured on a Shimadzu UV/vis-2450 spectrophotometer using methanol (Uvasol, Merk).

\section{Strain origin and Identification}

The Act24Zk strain was isolated from sand samples collected from the Caspian sea beach in north Iran on December 2016 by an isolation method originally designed for myxobacteria ${ }^{27}$ using St21 agar medium (solution $\mathrm{A}: \mathrm{K}_{2} \mathrm{HPO}_{4} 0.1 \%(\mathrm{w} / \mathrm{v}$ ); yeast extract (Difco) $0.002 \%(\mathrm{w} / \mathrm{v})$; Agar 1\% (w/v); solution B: $\mathrm{KNO}_{3} 0.1 \%(\mathrm{w} / \mathrm{v}), \mathrm{MgSO}_{4} \cdot 7 \mathrm{H}_{2} \mathrm{O} 0.1 \%(\mathrm{w} /$ v), $\mathrm{CaCl}_{2} \cdot 2 \mathrm{H}_{2} \mathrm{O} 0.1 \%(\mathrm{w} / \mathrm{v}), \mathrm{FeCl}_{3} 0.02 \%(\mathrm{w} / \mathrm{v}), \mathrm{MnSO}_{4} \cdot 7 \mathrm{H}_{2} \mathrm{O} 0.01 \%(\mathrm{w} / \mathrm{v})+100 \mu \mathrm{g} \mathrm{ml}^{-1}$ Cycloheximide). For molecular identification, the strain Act24Zk was cultured in $100 \mathrm{ml}$ of GYM medium and incubated for 3 days $\left(160 \mathrm{rpm}, 30^{\circ} \mathrm{C}\right)$. DNA extraction was performed using Invisorb Spin Plant Mini Kit, following the manufacturer's protocol. The 16S rRNA gene region was amplified by PCR using two universal primers, forward primers bind on the position (F27) and reverse primers bind on the position (R1541). The partial identification indicated that the strain Act $24 Z \mathrm{Zk}$ has $99.5 \%$ homology with $S$. xinjiangensis.

\section{Production, Extraction and Isolation}

A seed culture of strain Act24Zk was grown in a 250-ml flask, which contained $100 \mathrm{ml}$ of GYM medium $\left(0.4 \%\right.$ glucose, $0.4 \%$ yeast extract, $1 \%$ malt extract, $0.2 \% \mathrm{CaCO}_{3} ; \mathrm{pH} 7.2$; sterilized for $20 \mathrm{~min}$ at $121^{\circ} \mathrm{C}$ ) and incubated on a rotary shaker (160 rpm) for 7 days at 30 ${ }^{\circ} \mathrm{C}$. The production culture was transferred 1:10 in ninety $250 \mathrm{ml}$ flasks, filled with $100 \mathrm{ml}$ of medium 5294 ( $1 \%$ soluble starch, $0.2 \%$ yeast extract, $1 \%$ glucose, $1 \%$ glycerol, $0.25 \%$ corn 
steep liquor, $0.2 \%$ peptone, $\left.0.1 \% \mathrm{NaCl}, 0.3 \% \mathrm{CaCO}_{3} ; \mathrm{pH} 7.2\right)$ suspended in distilled water and sterilized for $20 \mathrm{~min}$ at $121{ }^{\circ} \mathrm{C}$. The flasks were incubated on a rotary shaker $(160 \mathrm{rpm})$ for nine days at $30{ }^{\circ} \mathrm{C}$. Mycelial biomass was separated from the culture broth by centrifugation $(5000 \mathrm{rpm}, 10 \mathrm{~min})$. The biomass was extracted with ethyl acetate three times (1.5 1).The combined ethyl acetate extracts were centrifuged and evaporated in vacuo. The residue $(2.0 \mathrm{~g})$ was redissolved in $100 \mathrm{ml}$ methanol containing 3\% of water and partitioned with $100 \mathrm{ml} n$-heptane three times. After evaporation the methanol layer yielded $1.34 \mathrm{~g}$ of a dark brown oily residue, which was separated by gel chromatography in two portions [column: Sephadex LH-20 $3 \times 830 \mathrm{~cm}$, flow rate $3.4 \mathrm{ml} \mathrm{min}^{-1}$, solvent methanol]. Totally six fractions were collected and tested against $S$. aureus and M. hiemalis. Fraction $2(240 \mathrm{mg})$ was further separated by preparative RP-HPLC [column $250 \times 21.2 \mathrm{~mm}$, Nucleodur Phenylhexyl, $5 \mu \mathrm{m}$ (Macherey Nagel), solvent A: water, solvent B: acetonitrile, gradient from $35 \% \mathrm{~B}$ to $75 \% \mathrm{~B}$ in $60 \mathrm{~min}$, flow rate $20 \mathrm{ml} \mathrm{min}^{-1}$, UV detection at 220, 280 and $360 \mathrm{~nm}$ ] to yield 1.0 $\mathrm{mg}$ saccharopyrone (2) and $1.1 \mathrm{mg}$ saccharonoic acid (3). Fraction 4 (180 mg) was purified by preparative RP-HPLC [column: $250 \times 21.2 \mathrm{~mm}$, Nucleodur 100-10 C18 (Macherey-Nagel); solvent A: water, solvent B: acetonitrile, gradient from $15 \%$ B to $35 \%$ B in $60 \mathrm{~min}$, flow rate $20 \mathrm{ml} \mathrm{min}-1$, UV detection at 220,300 and $360 \mathrm{~nm}$ ] and delivered $2.45 \mathrm{mg}$ of caerulomycin $\mathrm{M}$ (1) and $1.1 \mathrm{mg}$ caerulomycin A (4). The analytical HPLC profile of fr. 5 containing $8.79 \mathrm{mg}$ of 4 was found to be pure.

Caerulomycin M (1): yellow solid; $[\alpha]^{20}{ }_{\mathrm{D}}+54.7$ (c 0.3, MeOH); UV $\lambda_{\max }{ }^{\mathrm{MeOH}}(\log \varepsilon) 235$ (4.76), 281 (4.38 sh) nm; NMR data $\left({ }^{1} \mathrm{H}: 700 \mathrm{MHz},{ }^{13} \mathrm{C} 176 \mathrm{MHz}, \mathrm{DMSO}-d_{6}\right)$ see Table 1; HRESIMS: $[\mathrm{M}+\mathrm{H}]^{+} m / z$ 376.1509, calcd. 376.1503 for $\mathrm{C}_{18} \mathrm{H}_{22} \mathrm{~N}_{3} \mathrm{O}_{6},[2 \mathrm{M}+\mathrm{Na}]^{+} m / z 773.2738$, calcd. 773.2753 for $\mathrm{C}_{36} \mathrm{H}_{42} \mathrm{~N}_{6} \mathrm{NaO}_{12}, \mathrm{t}_{\mathrm{R}}=4.2 \mathrm{~min}$.

Saccharopyrone (2): colorless oil; $[\alpha]^{20}{ }_{\mathrm{D}}+25.5$ (c 0.04, MeOH); UV $\lambda_{\max }{ }^{\mathrm{MeOH}}(\log \varepsilon) 203$ (4.24), 285 (3.71); NMR data $\left({ }^{1} \mathrm{H}: 700 \mathrm{MHz},{ }^{13} \mathrm{C} 176 \mathrm{MHz}, \mathrm{DMSO}-d_{6}\right)$ see Table 1; HRESIMS: $[\mathrm{M}+\mathrm{Na}]^{+} \mathrm{m} / z$ 451.1937, calcd. 451.1939 for $\mathrm{C}_{21} \mathrm{H}_{32} \mathrm{NaO}_{9}, \quad[2 \mathrm{M}+\mathrm{Na}]^{+} \mathrm{m} / \mathrm{z}$ 879.3980, calcd. 879.3985 for $\mathrm{C}_{42} \mathrm{H}_{64} \mathrm{NaO}_{18}, \mathrm{t}_{\mathrm{R}}=7.7 \mathrm{~min}$.

Saccharonoic acid (3): yellow solid; $[\alpha]^{20}{ }_{\mathrm{D}}+22.7$ (c 0.3, MeOH); UV $\lambda_{\max }{ }^{\mathrm{MeOH}}(\log \varepsilon) 205$ (2.71), 264 (3.26) nm; NMR data $\left({ }^{1} \mathrm{H}: 700 \mathrm{MHz},{ }^{13} \mathrm{C} 176 \mathrm{MHz}, \mathrm{DMSO}-d_{6}\right)$ see Table 1; HRESIMS: $[\mathrm{M}+\mathrm{H}]^{+} \mathrm{m} / z$ 364.2841, calcd. 364.2846 for $\mathrm{C}_{22} \mathrm{H}_{38} \mathrm{NO}_{3},[2 \mathrm{M}+\mathrm{Na}]^{+} \mathrm{m} / z$ 727.5601, $t_{R}=15.6$ min.

\section{Acid hydrolysis of 1 and sugar analysis}

Determination of sugar moiety of caerulomycin A derivative was performed by hydrolysis according to Nakae et al. ${ }^{28}$ Compound $1(1.2 \mathrm{mg})$ was dissolved in $600 \mu 1$ of $8 \% \mathrm{HCl}-\mathrm{MeOH}$ and stirred at $60{ }^{\circ} \mathrm{C}$ for $24 \mathrm{~h}$. The hydrolysate was concentrated and purified by preparative 
TLC $\left(\mathrm{CHCl}_{3}: \mathrm{MeOH}: \mathrm{H}_{2} \mathrm{O}, 10: 5: 1\right)$ with $\alpha$-naphthol as visualizing agent to give pure Lrhamnopyranose 1a $(0.2 \mathrm{mg})$ and caerulomycin A, which were confirmed by LC/MS analysis. The optical rotations of $\mathbf{1 a}\left([\alpha]^{20}{ }_{\mathrm{D}}+16.0\left(c 0.04, \mathrm{H}_{2} \mathrm{O}\right)\right)$ and of the reference standard $\mathrm{L}(+)$ rhamnose monohydrate (Carl Roth $\mathrm{GmbH})\left([\alpha]^{20}{ }_{\mathrm{D}}+18.8\left(c 0.05, \mathrm{H}_{2} \mathrm{O}\right)\right)$ were determined.

\section{Biological assays}

\section{Antimicrobial assay}

Minimum inhibitory concentrations were determined by a serial dilution assay in 96-well plates with EBS medium for bacteria and MYC medium for fungi. ${ }^{29}$ Twenty microliter aliquots of compounds 1-4 with a concentration of $1 \mathrm{mg} \mathrm{ml}^{-1}$ (the end concentration in the first well is $67 \mu \mathrm{g} \mathrm{ml}^{-1}$ ) were tested against two different Gram-positive bacteria ( $S$. aureus, Micrococcus luteus), one Gram-negative bacterium (Escherichia coli Tol C) and two fungi (C. albicans, M. hiemalis) with methanol as a negative control.

\section{Cytotoxicity assay}

Cytotoxicity $\left(\mathrm{IC}_{50}\right)$ of compounds 1-4 was determined against two human cancer cell lines (normal cell line mouse fibroblasts L929, HeLa cells KB3.1) by using a 5-day MTT assay according to an established procedure. ${ }^{30}$

\section{CONFLICT OF INTERESTS}

The authors declare no conflict of interest.

\section{ACKNOWLEDGEMENTS}

We thank C. Risdian for assistance in the identification of bacterial strain Act24Zk, A. Gollasch and S. Karwehl for measuring the mass spectra, as well as C. Kakosche for recording NMR spectra and W. Collisi for conduction of bioassays.

Supplementary Information is linked to the online version of the paper at www.nature.com/ nature

\section{REFERENCES}

1. Banin E, Hughes D, Kuipers OP. Bacterial pathogens, antibiotics and antibiotic resistance. FEMS Microbiol. Rev. 2017, 41: 450-452. 
2. Ibeyaima A, Dwivedi AK, Saini N, Gupta S, Sarethy IP. Saccharothrix sp. TD-093 from the Thar desert, India: metabolite fingerprinting of antimicrobial compounds and in silico analysis. Curr. Microbiol. 2017, 74: 334-343.

3. Dewi TK, Agustiani D, Antonius S. Secondary metabolites production by Actinomycetes and their antifungal activity. KnE Life Sci. 2017, 3: 256-264.

4. Bahri A, Moazamian E, Azarpira N. Identification, isolation and evaluation of Persian Gulf actinomycetes as candidates of cytotoxic metabolites against breast cancer. Multidiscip. Cancer Investig. 2017, 1: 10-14.

5. Van der Meij A, Worsley SF, Hutchings MI, van Wezel GP. Chemical ecology of antibiotic production by actinomycetes FEMS Microbiol. Rev. 2017; 41: 392-416.

6. Lu S, Nishimura S, Ito M, Tsuchida T, Kakeya H. Isolation and structure elucidation of cytotoxic saccharothriolides D to F from a rare actinomycete Saccharothrix sp. and their structure-activity relationship J. Nat. Prod. 2016, 79: 1891-1895.

7. Boubetra D, Zitouni A, Bouras N, Mathieu F, Lebrihi A, Schumann P.et al. Saccharothrix hoggarensis sp. nov., an actinomycete isolated from Saharan soil Int. J. Syst. Evol. Microbiol. 2013; 63: 549-553.

8. Solecka J, Zajko J, Postek M, Rajnisz A. Biologically active secondary metabolites from Actinomycetes Cent. Eur. J. Biol., 2012, 7: 373-390.

9. Lu S, Nishimura S, Ito M, Kato T, Kakeya H. Precursor-directed in situ synthesis of saccharothriolides $\mathrm{G}$ and $\mathrm{H}$ by the actinomycete Saccharothrix sp. A1506. J. Antibiot. 2017, 70: 718.

10. Zhang XG, Liu ZY, Liu JW, Zeng YL, Guo GJ, Sun QY. Antitumor activity of a Rhodococcus sp. Lut0910 isolated from polluted soil. Tumor Biol. 2017, 39: 10104283177116611.

11. Wang X, Tabudravu J, Jaspars M, Deng H. Tianchimycins A-B, 16-membered macrolides from the rare actinomycete Saccharothrix xinjiangensis. Tetrahedron 2013, 69: 6060-6064.

12. Lu S, Nishimura S, Hirai G, Ito M, Kawahara T, Izumikawa M, Soseoka et al. Saccharothriolides A-C, novel phenyl-substituted 10-membered macrolides isolated from a rare actinomycete Saccharothrix sp. Chem. Commun. 2015, 51: 8074-8077.

13. Kinoshita N, Igarashi M, Ikeno S, Hori M. Hamada M. Saccharothrix tangerinus sp. nov., the producer of the new antibiotic formamicin: taxonomic studies.

Actinomycetol. 1990, 13: 20-31.

14. Hu YT, Zhou PJ, Zhou YG, Liu ZH, Liu SJ. Saccharothrix xinjiangensis sp. nov., a pyrene-degrading actinomycete isolated from Tianchi Lake, Xinjiang, China. Int. J. Syst. Evol. Microbiol. 2004, 54: 2091-2094.

15. Divekar PV, Read G, Vining LC. Caerulomycin, a new antibiotic from Streptomyces caeruleus Baldacci. II. Structure. Can. J. Chem. 1969, 45: 1215.

16. Dutton GGS, Merrifield EH, Laffite C, Pratviel-Sosa F, Wylde R. Comparative NMR study of rhamnobioses - applications. Org. Magn. Reson. 1982, 20: 154-158.

17. Lahoum A, Sabaou N, Bijani C, Bouras, N, Pont F, Snini SP et al. Antimicrobial activities of novel bipyridine compounds produced by a new strain of Saccharothrix isolated from Saharan soil. Saudi Pharma. J. 2018. https://doi.org/10.1016/j.jsps.

18. Schäberle TF. Biosynthesis of $\alpha$-pyrones . J. Org. Chem. 2016, 12: 571-588. 
19. Sucipto H, Sahner JH, Prusov E, Wenzel SC, Hartmann RW, Koehnke J, Müller R. In vitro reconstitution of $\alpha$-pyrone ring formation in myxopyronin biosynthesis. Chem. Sci. 2015, 6, 5076-5085.

20. Sucipto H, Wenzel SC, Müller R. Exploring chemical diversity of $\alpha$-pyrone antibiotics: Molecular basis of myxopyronin biosynthesis. ChemBioChem 2013, 14, 1581-1589. doi:10.1002/cbic.201300289.

21. Stahl M, Schopfer U, Frenking G, Hoffmann RW. Assignment of relative configuration to acyclic compounds based on 13C NMR shifts. A density functional and molecular mechanics study. J. Org. Chem. 1996, 61: 8083-8088.

22. Hoffmann RW. Flexible molecules with defined shape - conformational design. Angew. Chem. 1992, 104: 1147. Angew. Chem., Int. Ed. Engl. 1992, 31 : 1124.

23. Schwecke T, Aparicio JF, Molnár I, König A, Khaw LE; Haydock SF et al. The biosynthetic gene cluster for the polyketide immunosuppressant rapamycin. Proc. Natl. Acad. Sci. USA 1995, 92: 7839-7843.

24. Xue Y, Zhao L, Liu HW, Sherman HW. A gene cluster for macrolide antibiotic biosynthesis in Streptomyces venezuelae: architecture of metabolic diversity.Proc. Natl. Acad. Sci. USA 1998, 95: 12111-12116.

25. Akhmedov NG, Gannett PM, Wu B, Cummings MM, Train BC. A conformational NMR analysis of methymycin aglycones: complete and unambiguous assignments of stereochemically diverse glycosylated methymycin analogs by 1D and 2D NMR techniques and molecular modeling. Magn. Res. Chem. 2013, 51: 156-167.

26. Funk A, Divekar PV. Caerulomycin, a new antibiotic from Streptomyces caeruleus Baldacci: I. production, isolation, assay, and biological properties. Can. J. Microbiol. 1959, 5: 317-321.

27. Shimkets LJ, Dworkin M, Reichenbach H. The Prokaryotes: A Handbook on the Biology of Bacteria, 7, New York Springer; 2006, p. 31-115.

28. Nakae K, Kurata I, Kojima F, Igarashi M, Hatano M, Sawa R. Sacchathridine A, a prostaglandin release inhibitor from Saccharothrix sp. J. Nat. Prod. 2013, 76: 720722.

29. Surup F, Pommerrehne K, Schroers HJ, Stadler M. Elsinopirins A-D, decalin polyketides from the ascomycete Elsinoë pyri. Biomolecules 2018, https://doi.org/10.3390/biom8010008.

30. Chepkirui C, Sum WC, Cheng T, Matasyoh JC, Decock C, Stadler M Aethiopinolones A-E, new pregnenolone type triterpenes from the East African basidiomycete Fomitiporia aethiopica. Molecules 23:369, https:// doi.org/10.3390/molecules23020369

\section{Titles and legends to figures}


Figure 1. Structures of metabolites 1-4 from S. xinjiangensis.

Figure 2. Selected COSY (bold bonds), HMBC (plain arrows) and ROESY (dashed arrows) correlations of $\mathbf{1}$.

Figure 3. Selected COSY (bold bonds), HMBC (plain arrows) and ROESY (dashed arrows) correlations of 2 .

Figure 4. Selected COSY (bold bonds) and HMBC (plain arrows) correlations of 3.

Figure 5. MM2 calculated model of 3 (ChemBio3D 17.1) and selected ROESY correlations. Plain lines upper side NOEs, dashed lines lower side NOEs. 


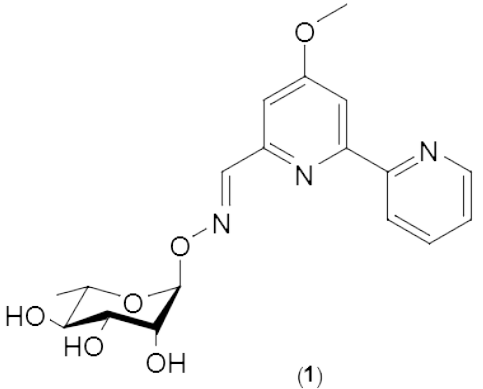<smiles>CC(C=CC(=O)NCC(=O)O)=CC(C)CC(C)CC(C)=CCCC(C)C</smiles>

(3)<smiles></smiles>

(2)

Figure 1. Structures of metabolites 1-4 from S. xinjiangensis.

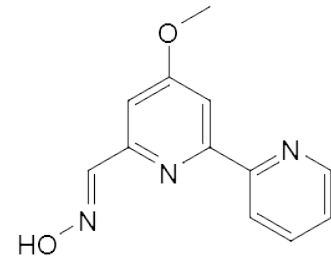

(4) 


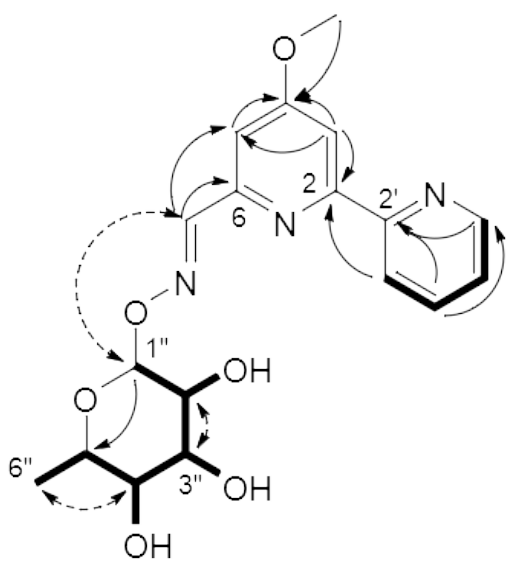

Figure 2. Selected COSY (bold bonds), HMBC (plain arrows) and ROESY (dashed arrows) correlations of $\mathbf{1}$. 


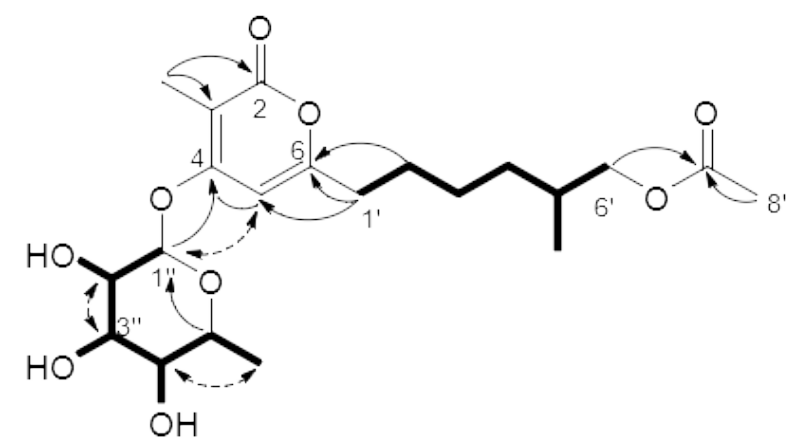

Figure 3. Selected COSY (bold bonds), HMBC (plain arrows) and ROESY (dashed arrows) correlations of 2 . 


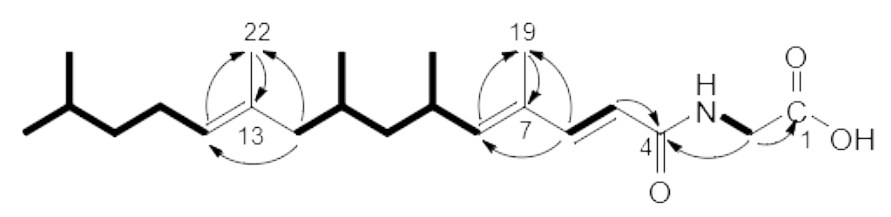

Figure 4. Selected COSY (bold bonds) and HMBC (plain arrows) correlations of 3. 


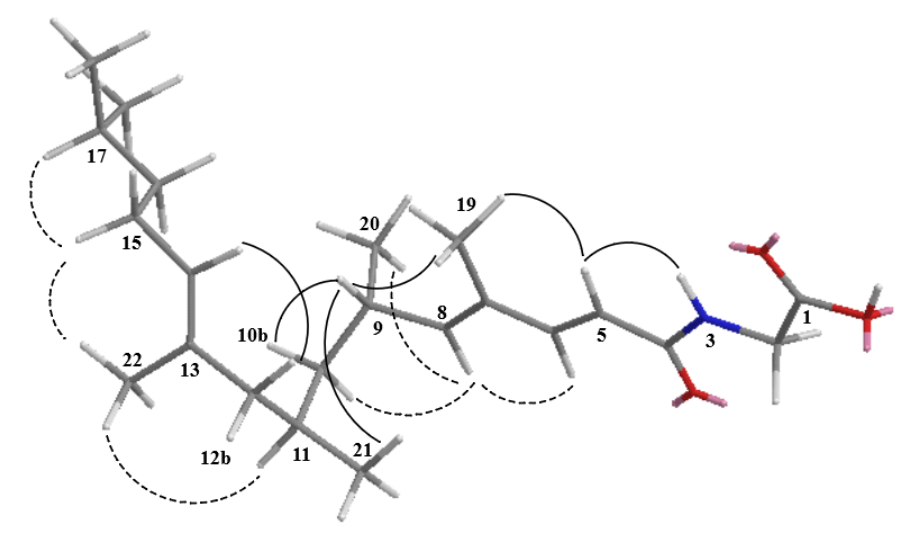

Figure 5. MM2 calculated model of 3 (ChemBio3D 17.1) and selected ROESY correlations. Plain lines: upper side NOEs, dashed lines: lower side NOEs.

Table 1. NMR data of compounds $\mathbf{1}-\mathbf{3}$ in DMSO- $d_{6}\left({ }^{1} \mathrm{H} 700.4 \mathrm{MHz},{ }^{13} \mathrm{C} 176.1 \mathrm{MHz}\right)$ 


\begin{tabular}{|c|c|c|c|c|c|c|}
\hline \multirow[b]{2}{*}{ Pos. } & \multicolumn{2}{|c|}{1} & \multicolumn{2}{|r|}{2} & \multicolumn{2}{|c|}{3} \\
\hline & $\delta_{\mathrm{C}}$, type & $\begin{array}{l}\delta_{\mathrm{H},}, \mathrm{m} \\
\mathrm{Hz})\end{array}$ & $\delta_{\mathrm{C}, \text { type }}$ & $\delta_{\mathrm{H},} \mathrm{m}(J$ in $\mathrm{Hz})$ & $\delta_{\mathrm{C}}$, type & $\begin{array}{l}\delta_{\mathrm{H},} \mathrm{m} \\
\mathrm{Hz})\end{array}$ \\
\hline 1 & - & - & - & - & $171.2, \mathrm{C}$ & - \\
\hline 2 & 157.1, C & - & $164.5, \mathrm{C}$ & - & $41.5, \mathrm{CH}_{2}$ & $3.73, \mathrm{~d}(5.6)$ \\
\hline 3 & 107.2, CH & $7.96^{a}, \mathrm{~d}(2.4)$ & 101.0, C & - & $\mathrm{NH}$ & 8.05, br. s \\
\hline 4 & $166.8, \mathrm{C}$ & - & $162.9, \mathrm{C}$ & - & $165.5, \mathrm{C}$ & \\
\hline 5 & $106.9, \mathrm{CH}$ & 7.37, d (2.4) & $96.4, \mathrm{CH}$ & $6.47, \mathrm{~s}$ & $119.5, \mathrm{CH}$ & $6.02, \mathrm{~d}(15.5)$ \\
\hline 6 & 151.9, C & - & 163.1, C & - & $143.9, \mathrm{CH}$ & $7.01, \mathrm{~d}(15.5)$ \\
\hline 7 & $151.3, \mathrm{CH}$ & $8.33, \mathrm{~s}$ & $8.5, \mathrm{CH}_{3}$ & $1.79, \mathrm{~s}$ & $130.5, \mathrm{C}$ & - \\
\hline 8 & $55.8, \mathrm{CH}_{3}$ & $3.97, \mathrm{~s}$ & & & 145.7, CH & $5.62, \mathrm{~d}(9.7)$ \\
\hline 9 & & & & & $30.6, \mathrm{CH}$ & $2.63, \mathrm{~m}$ \\
\hline \multirow[t]{2}{*}{10} & & & & & 44.1, $\mathrm{CH}_{2}$ & $\begin{array}{l}\text { (a) } 1.09 \text {,ddd } \\
\text { (11.2, } 1.1 \text {, }\end{array}$ \\
\hline & & & & & & (b) $1.23, \mathrm{~m}$ \\
\hline 11 & & & & & $28.1, \mathrm{CH}$ & $1.53^{a}, \mathrm{~m}$ \\
\hline \multirow[t]{2}{*}{12} & & & & & 47.0, $\mathrm{CH}_{2}$ & $\begin{array}{l}\text { (a) } 1.64, \mathrm{dd} \\
(13.0,8.4)\end{array}$ \\
\hline & & & & & & $\begin{array}{l}\text { (b) } 1.97^{b}, \mathrm{dd} \\
(13.0,5.6)\end{array}$ \\
\hline 13 & & & & & $133.1, \mathrm{C}$ & - \\
\hline 14 & & & & & $126.0, \mathrm{CH}$ & $5.05, \mathrm{t}(6.9)$ \\
\hline 15 & & & & & $25.2, \mathrm{CH}_{2}$ & $\begin{array}{l}1.95^{b}, \mathrm{dt}(6,9, \\
6.5)\end{array}$ \\
\hline 16 & & & & & $38.6, \mathrm{CH}_{2}$ & $\begin{array}{l}1.18, \mathrm{dt}(7.5 \text {, } \\
7.1)\end{array}$ \\
\hline 17 & & & & & $26.9, \mathrm{CH}$ & $1.51^{a}, \mathrm{~m}$ \\
\hline 18 & & & & & $22.4, \mathrm{CH}_{3}$ & $\begin{array}{l}0.85 \text {, dd (6.6, } \\
1.4)\end{array}$ \\
\hline 19 & & & & & $12.4, \mathrm{CH}_{3}$ & $1.75, \mathrm{~d}(0.9)$ \\
\hline 20 & & & & & $20.4, \mathrm{CH}_{3}$ & $0.91, \mathrm{~d}(6.5)$ \\
\hline 21 & & & & & $19.8, \mathrm{CH}_{3}$ & $0.76, d(6.5)$ \\
\hline 22 & & & & & $15.5, \mathrm{CH}_{3}$ & $1.48, \mathrm{~s}$ \\
\hline $1^{\prime}$ & & . & $32.8, \mathrm{CH}_{2}$ & $2.48, \mathrm{t}(7.3)$ & & \\
\hline $2^{\prime}$ & 154.3, C & - & 26.5, $\mathrm{CH}_{2}$ & $1.55, \mathrm{~m}$ & & \\
\hline \multirow[t]{2}{*}{$3^{\prime}$} & $120.8, \mathrm{CH}$ & $8.39, \mathrm{~d}(7.9)$ & $25.4, \mathrm{CH}_{2}$ & (a) $1.27, \mathrm{~m}$ & & \\
\hline & & & & (b) $1.34^{a}, \mathrm{~m}$ & & \\
\hline $4^{\prime}$ & $137.4, \mathrm{CH}$ & $\begin{array}{l}7.97^{a}, \mathrm{ddd} \\
(7.9,7.5,1.7)\end{array}$ & $32.3, \mathrm{CH}_{2}$ & $\begin{array}{l}\text { (a) } 1.13, \mathrm{~m} \\
\text { (b) } 1.35^{a}, \mathrm{~m}\end{array}$ & & \\
\hline $5^{\prime}$ & 124.7, CH & $\begin{array}{l}7.49, \text { ddd } \\
(7.5,4.7,1.1)\end{array}$ & $31.9, \mathrm{CH}_{2}$ & $1.71, \mathrm{~m}$ & & \\
\hline \multirow[t]{2}{*}{$6^{\prime}$} & $149.3, \mathrm{CH}$ & $8.70, \mathrm{~d}(4.7)$ & $68.4, \mathrm{CH}_{2}$ & $\begin{array}{l}\text { (a) } 3.79, \mathrm{dd} \\
(10.7,6.7)\end{array}$ & & \\
\hline & & & & $\begin{array}{l}\text { (b) } 3.87, \mathrm{dd} \\
(10.7,5.8)\end{array}$ & & \\
\hline $7^{\prime}$ & & & $170.4, \mathrm{C}$ & - & & \\
\hline $8^{\prime}$ & & & $20.7, \mathrm{CH}_{3}$ & $2.01, \mathrm{~s}$ & & \\
\hline $9^{\prime}$ & & & $16.6, \mathrm{CH}_{3}$ & $0.86, \mathrm{~d}(6.7)$ & & \\
\hline $1 "$ & $103.1, \mathrm{CH}$ & $5.35, \mathrm{~d}(1.7)$ & $97.8, \mathrm{CH}$ & $5.59, \mathrm{~d}(1.9)$ & & \\
\hline $2^{\prime \prime}$ & $69.1, \mathrm{CH}$ & $3.84, \mathrm{t}(3.4)$ & $69.7, \mathrm{CH}$ & $3.83, \mathrm{t}(3.4)$ & & \\
\hline
\end{tabular}




\begin{tabular}{|c|c|c|c|c|}
\hline $3 "$ & 70.6, CH & $\begin{array}{l}3.50^{b}, \mathrm{dd} \\
(9.3,3.4)\end{array}$ & $70.3, \mathrm{CH}$ & $\begin{array}{l}3.60 \text {, dd (9.3, } \\
3.4)\end{array}$ \\
\hline 4" & $71.8, \mathrm{CH}$ & $\begin{array}{l}3.29 \text {, dd (9.3, } \\
9.7)\end{array}$ & $71.4, \mathrm{CH}$ & $3.28, \mathrm{t}(9.7)$ \\
\hline $5^{\prime \prime}$ & 69.7,CH & $\begin{array}{l}3.52^{b}, \mathrm{dq} \\
(9.7,6.3)\end{array}$ & $70.4, \mathrm{CH}$ & $\begin{array}{l}3.35 \text {, dq }(9.7 \text {, } \\
6.0)\end{array}$ \\
\hline 6" & $18.0 ; \mathrm{CH}_{3}$ & $1.15, \mathrm{~d}(6.3)$ & 17.6, $\mathrm{CH}_{3}$ & $1.11, \mathrm{~d}(6.0)$ \\
\hline $\begin{array}{l}2 "- \\
\mathrm{OH}\end{array}$ & - & 5.08, br. s & - & 5.18, br. s \\
\hline 3"- & - & 4.78, br. s & - & 4.84 , br. s \\
\hline \multicolumn{5}{|l|}{$\mathrm{OH}$} \\
\hline 4"- & - & 4.90, br. s & - & 4.94 , br. s \\
\hline $\mathrm{OH}$ & & & & \\
\hline
\end{tabular}

${ }^{a, b}$ Overlapping signals. Chemical shifts were assigned from ${ }^{1} \mathrm{H},{ }^{13} \mathrm{C}$ HSQC spectrum.

Table 2. Antimicrobial and cytotoxic activities of 1-4 


\begin{tabular}{|c|c|c|c|c|c|}
\hline & 1 & 2 & 3 & 4 & oxytetracyline \\
\hline Microorganisms & \multicolumn{5}{|c|}{$\operatorname{MIC}\left(\mu \mathrm{g} \mathrm{ml}^{-1}\right)$} \\
\hline Staphylococcus aureus Newman & - & - & - & 4.2 & 0.1 \\
\hline Micrococcus luteus DSM1790 & - & - & - & 4.2 & 0.4 \\
\hline \multirow[t]{2}{*}{ Escherichia coli DSM1116 } & - & - & - & 8.3 & 1.7 \\
\hline & & & & & nystatin \\
\hline Mucor hiemalis DSM2656 & 16.7 & - & 66.7 & 4.2 & 4.2 \\
\hline Candida albicans DSM1665 & - & - & 33.4 & - & 8.8 \\
\hline Cell lines & \multicolumn{4}{|c|}{$\mathrm{IC}_{50}(\mu \mathrm{M})$} & epothilon B \\
\hline Mouse fibroblasts L929 & 50.7 & 30.4 & - & 0.1 & $1.9 \cdot 10^{-3}$ \\
\hline HeLa cells KB3.1 & 40.0 & 5.4 & - & 0.2 & $0.5 \cdot 10^{-3}$ \\
\hline
\end{tabular}

-: not active. Positive control: oxytetracycline, nystatin, epothilon B 